\title{
Validation of the Brazilian version of the neurological fatigue index for multiple sclerosis
}

\author{
Validação da versão brasileira do índice neurológico de fadiga na esclerose múltipla \\ Josiane Lopes ${ }^{1}$, Edson Lopes Lavado², Damacio Ramón Kaimen-Maciel ${ }^{3}$
}

\begin{abstract}
The Neurological Fatigue Index for Multiple Sclerosis (NFI-MS) is a new fatigue assessment instrument. The aim of this study was to cross-culturally adapt and assess the psychometric properties of the Brazilian version of the NFI-MS (NFI-MS/BR). Method: Two hundred and forty subjects with MS were recruited for this study. The adaptation of the NFI-MS was performed by translation and back translation methodology. In psychometric analysis was performed the administration of the questionnaires Epworth Sleep Scale, Fatigue Severity Scale, Modified Fatigue Impact Scale, Multiple Sclerosis Impact Scale-29, NFI-MS/BR and Pittsburgh Sleep Quality Index with retest of the NFI-MS/BR after 7 days. Results: Reliability was assessed (intraclass correlation coefficients between 0.77 and 0.86 ), and validity by testing 41 hypotheses about expected correlations between subscales and confirmed 36. The majority of correlations were demonstrated. Conclusion: The NFI-MS/BR is a cross-culturally adapted, valid, and reliable instrument for assessing MS fatigue among Brazilian subjects.
\end{abstract}

Keywords: multiple sclerosis; fatigue; assessment; validation studies; psychometrics.

\section{RESUMO}

O índice neurológico de fadiga na esclerose múltipla (EM) (NFI-MS) é um novo instrumento de avaliação da fadiga. O objetivo deste estudo foi adaptar transculturalmente e avaliar as propriedades psicométricas da versão Brasileira do NFI-MS (NFI-MS/BR). Método: Duzentos e quarenta indivíduos com EM participaram deste estudo. A adaptação do NFI-MS/BR foi feita por meio de tradução e retrotradução. $\mathrm{Na}$ análise psicométrica foi realizada administração dos questionários Escala de Sono de Epworth, Escala de Severidade de Fadiga, Escala Modificada de Impacto de Fadiga, Escala de Impacto de EM, NFI-MS/BR e Índice de Qualidade de Sono de Pittsburgh com reteste do NFI-MS/BR em 7 dias. Resultados: A confiabilidade foi avaliada (coeficiente de correlação intraclasse entre 0,77 e 0,86), e a validade foi avaliada testando 41 hipóteses sobre as correlações esperadas com confirmação de 36 hipóteses. A maioria das correlações da validade de constructo foi demonstrada. Conclusão: O NFI-MS/BR é um instrumento adaptado transculturalmente, válido e confiável para avaliar fadiga em indivíduos brasileiros com EM.

Palavras-chave: esclerose múltipla; fadiga; avaliação; estudos de validação; psicometria.

Fatigue is the most frequent and severe of symptoms causing morbidity and disability in multiple sclerosis (MS) patients. However, measuring fatigue is a difficult task. There is no clear definition; it is complex and multidimensional, and is a highly subjective symptom with many uncertainties regarding its pathophysiology. No biological or neuroimaging markers for fatigue are currently known ${ }^{1}$.

The lack of standardization for fatigue measurement has resulted in development of several assessment instruments, but none of them is universally accepted. The Fatigue Severity Scale (FSS) ${ }^{2}$ and Modified Fatigue Impact Scale (MFIS) ${ }^{3}$ are the most widely used instruments for measuring MS fatigue, although limitations regarding their development and measurement properties have been reported. Moreover, they were not specifically developed for MS patients ${ }^{4,5.6}$. Studies using the Rasch measurement model have identified a need for certain items to be removed from the FSS [4] and MFIS [6] so that their measurements can be considered valid and reliable.

In Brazil, FSS 7 and MFIS ${ }^{8}$ have been widely used, despite the failings of their design and psychometric properties in Brazilian cross-cultural adaptation studies. These Brazilian versions did not fulfill the criteria for adequate sample size and design. Moreover, the psychometric properties of the Brazilian FSS adaptation were not assessed. Therefore, there are no Brazilian MS-specific instrument for assessing fatigue with reported methodological and psychometric properties

\footnotetext{
1Universidade Estadual de Londrina, Programa de Pós Graduação em Ciências da Saúde, Londrina PR, Brazil;

${ }^{2}$ Universidade Estadual de Londrina, Departamento de Fisioterapia, Londrina PR, Brazil;

${ }^{3}$ Universidade Estadual de Londrina, Departamento de Clínica Médica, Londrina PR, Brazil.

Correspondence: Josiane Lopes; Avenida Inglaterra, 155; 86046-000 Londrina PR, Brasil; E-mail: josianelopes@yahoo.com.br

Conflict of interest: There is no conflict to interest to declare.

Received 26 October 2015; Received in final form 26 October 2015; Accepted 05 January 2016.
} 
of design and administration that can satisfy the current standards for outcome measurements.

Concerns regarding the quality of existing measurements led Mills et al. ${ }^{5}$ to develop the 'Neurological Fatigue Index for MS' (NFI-MS), with rigorous methodology that fulfills current scale development criteria and has the psychometric properties satisfying Rasch measurement model expectations. This instrument provides a potential guide for MS fatigue assessment that can be used in research and clinical practice $9,10,11,12$. However, it has limited worldwide applicability, with published adaptation only for British English ${ }^{5}$ and Dutch ${ }^{13}$, although it has been simply adapted into many languages for clinical trial purposes. The aim of the present study was to cross-culturally adapt and assess the psychometric properties of a Brazilian version of the NFI-MS.

\section{METHOD}

\section{Subjects}

Brazilians subjects were recruited with MS, diagnosed in accordance with the revised McDonald criteria ${ }^{14}$, no relapses during the last 90 days and Expanded Disability Status Scale $(E D S S)^{15} \leq 7.5$ points. Subjects with other neurological, cardiac or pulmonary diseases were excluded. The sample size of 240 subjects was estimated in accordance with the criteria recommended for adaptation (30 subjects) and for validation study design (210 subjects) ${ }^{16}$. The study was approved by the Institutional Research Ethic Committee of State University of Londrina (code 211/2011). All subjects were informed about the objectives of the study and signed the informed consent statement.

\section{Instrument}

\section{Neurological Fatigue Index-MS}

The NFI-MS 5 is a questionnaire that comprises 23 items on four different unidimensional subscales: physical (eight items), cognitive (four items), relief through diurnal sleep or rest (six items) and abnormal nocturnal sleep and sleepiness (five items). All the items are worded such that they are scored in the same direction with Likert responses ('strongly disagree', 'disagree', 'agree' and 'strongly agree') scored from 0 to 3 , giving a variable score range for each of the subscales. A higher score implies greater physical or cognitive fatigue. A summary NFI-MS score can be calculated containing 10 items from both domains (items 1 to 7 from physical subscale and items 9,11 , and 12 from cognitive subscale). Both sleep domains were only regarded as provisional in the original publication ${ }^{5}$.

\section{Procedures}

The subjects were assessed using a socio-clinical questionnaire, and the EDSS ${ }^{15}$, which were administered by the same neurologist. Following this, they were included either in Phase 1 or in Phase 2 of the study, according to the sequence of recruitment.

\section{Phase 1: Cross-cultural adaptation of the NFI-MS}

The NFI-MS was culturally adapted from English to Brazilian Portuguese language in accordance with the guidelines proposed by Beaton et al. ${ }^{16}$. The translations were performed by two native Portuguese translators independently. The translations were synthesized into a single Portuguese version by the translators and a third person (a healthcare professional). Subsequently, this Portuguese version was back-translated into English independently by two British native translators. The backward translations were synthesized by the translators and compared with the NFI-MS. The forward and backward translations were submitted to a bilingual expert committee (biostatistician, epidemiologist, linguist, neurologists, nurse, psychologist, physiotherapist and the translators) to analyze the equivalences. Subsequently, a trained interviewer administered the Brazilian version of the NFI-MS (NFI-MS/BR) to $30 \mathrm{MS}$ subjects to verify their comprehension of the instrument. At the end of this process, the NFI-MS/BR was ready for psychometric testing [Additional file 1].

The content validity was assessed by the expert committee, by verifying the conceptual, cultural, idiomatic and semantic equivalences between the NFI-MS/BR and NFI-MS ${ }^{5}$. The group of 30 patients enrolled into cross-cultural adaptation only answered whether understand the items.This is only a small part of content validity that also includes face validity and extends to the degree to which the content of a questionnaire is adequate to be measured ${ }^{16,17}$. Besides this stage, additional testing for all psychometric properties is highly recommended.

\section{Phase 2: Assessment of psychometric properties}

In this phase, 210 MS subjects were assessed. Testing-retesting was applied to the first 30 subjects by means of phone calls: interviewers $\mathrm{A}$ and $\mathrm{B}$ administered the NFI-MS/BR separately with a one-hour interval between them and then, seven days later, interviewer A performed the retesting to 30 subjects.

A questionnaire pack was applied to the remaining 180 MS subjects, and included the Epworth Sleepiness scale (ESS) ${ }^{17}$; FSS ${ }^{7}$ : MFIS ${ }^{8}$; Multiple Sclerosis Impact Scale (MSIS-29) ${ }^{18}$; NFI-MS/BR and the Pittsburgh Sleep Quality Index (PSQUI) ${ }^{19}$. This was done by interviewer B in a separate room on the day of the subjects' consultation in the hospital-based outpatient clinic. The subjects were instructed that they should answer the questionnaires individually, and the time taken was recorded by means of a digital chronometer. All questionnaires were administered as interviews to pattern data collection. 


\section{Statistical analysis}

The statistical analysis was performed using the Statistical Package for the Social Sciences (SPSS ${ }^{\circ}$, Release 20.0), and MedCalc ${ }^{\circ}$ (Release 11.1.1.0). The normality of data distribution was checked by means of the Shapiro-Wilk test. The data were described as medians with the interquartile range [25\%-75\%].

Based on the Instrument Review Criteria ${ }^{20}$, the psychometric properties of the NFI-MS/BR were analyzed. The data quality was accepted if the proportion of missing data was $<20 \%$. The time taken to apply the NFI-MS/BR and the score distributions of floor and ceiling effects were also taken into consideration in assessing the acceptability.

The reliability was examined by the reproducibility and measurement error. The reproducibility was tested by means of testing-retesting using the intraclass correlation coefficient (ICC) and the Bland-Altman method with mean differences. The ICC was calculated in two-way random effects model for agreement with optimal values were taken ICC $\geq 0.70$. Measurement error was assessed by calculating the standard error of the measurement (SEM). SEM agreement was derived from the error variance in the ICC formula [21].

The construct validity was tested through correlations between the NFI-MS/BR and subscale scores of other instruments, taking the following defined hypotheses into consideration:

- Similar subscales of the instruments that measure the same construct show high correlations (NFI-MS physical and MFIS physical, NFI-MS physical and MSIS-29 physical, NFI-MS physical and FSS, NFI-MS physical and EDSS, NFI-MS cognitive and MFIS cognitive, NFI-MS cognitive and MSIS-29 Psychological, NFI-MS diurnal sleep and ESS, NFI-MS diurnal sleep and PSQUI, NFI-MS nocturnal sleep and ESS, NFI-MS nocturnal sleep and PSQUI).

- Non-similar subscales of the instruments that measure the same construct show low or moderate correlations (NFI-MS subscales and MFIS subscales or FSS, MSIS-29, ESS, PSQUI, EDSS).

Correlations were estimated using Spearman's correlation coefficients $($ rho $)(0.25 \leq$ rho $<0.50=$ low; $0.50 \leq r h o \leq 0.75=$ moderate; and $r h o>0.75=$ high correlation $)^{21}$.

A receiver operating characteristic (ROC) curve was drawn to provide a sensitivity, specificity ratio and accuracy of NFI-MS/BR. Accuracy test of a instrument can be determined from sensitivity and specificity with the presence of prevalence, expressed as a proportion of correctly classified subjects. For this method it was used the data of all subjects. It was considered FSS $\geq 28$ as cut-off point to indicate fatigued subjects?

\section{RESULTS}

Table 1 shows characteristics of the 240 MS subjects. In Table 2, the distribution of scores on the scales is described.

\section{Cross-cultural adaptation of the NFI-MS to the}

\section{Portuguese language}

The translation and back-translation versions were similar to the NFI-MS. Only three items were changed. Items 13 and 14 showed the Portuguese translation of the verb "to need" as "precisar" and it was changed to "necessitar" due to express a better context. Item 16, "O descanso permite continuar minhas atividades", was changed to "Eu necessito descansar para continuar minhas atividades".

Use of the word 'fatigue' was avoided because of semantic ambiguity. After these changes, full equivalences of the NFI-MS/BR were achieved. In pretesting, no subject demonstrated any problem in understanding the instrument, and thus the instrument showed content and face validity. The NFI-MS/BR kept the same number and allocation of items, domains, format and response patterns as original version?.

Table 1. Study sample characteristics in cross-cultural adaptation and psychometric property phases.

\begin{tabular}{|c|c|c|}
\hline Variable & $\begin{array}{c}\text { Adaptation } \\
\text { sample }(n=30)\end{array}$ & $\begin{array}{c}\text { Validation } \\
\text { sample }(n=210)\end{array}$ \\
\hline \multicolumn{3}{|l|}{ Age (years) } \\
\hline Median (IQR) & $42.5(28-51.5)$ & $39(29-50)$ \\
\hline \multicolumn{3}{|l|}{ Gender n (\%) } \\
\hline Female & $24(80)$ & $160(76.1)$ \\
\hline Male & $6(20)$ & $50(23.8)$ \\
\hline \multicolumn{3}{|l|}{ Ethnicity n (\%) } \\
\hline Caucasian & $26(86.6)$ & $158(75.2)$ \\
\hline Non-Caucasian & $4(13.3)$ & $52(24.7)$ \\
\hline \multicolumn{3}{|l|}{ Education n (\%) } \\
\hline Incomplete elementary & $0(0)$ & $12(5.7)$ \\
\hline Elementary & $10(33.3)$ & $36(17.1)$ \\
\hline High School & $10(33.3)$ & $78(37.1)$ \\
\hline Higher education & $10(33.3)$ & $84(40.0)$ \\
\hline \multicolumn{3}{|l|}{ Years since diagnosis (years) } \\
\hline Median (IQR) & $8.6(5.3-10.9)$ & $5.25(2.25-9.95)$ \\
\hline \multicolumn{3}{|l|}{ Age at diagnosis (years) } \\
\hline Median (IQR) & $30.5(23.7-42)$ & $31(24.5-41.5)$ \\
\hline \multicolumn{3}{|l|}{ MS clinical form n (\%) } \\
\hline Relapsing remitting & $24(80)$ & $171(81.4)$ \\
\hline Secondary progressive & $5(16.6)$ & $16(7.6)$ \\
\hline Clinically isolated & $1(3.3)$ & $14(6.6)$ \\
\hline Primary progressive & $0(0)$ & $6(2.8)$ \\
\hline Not defined & $0(0)$ & $3(1.4)$ \\
\hline \multicolumn{3}{|l|}{ EDSS } \\
\hline Median (IQR) & $3(1.75-4)$ & $3(1-4)$ \\
\hline *Fatigue n (\%) & - & $136(75.5)$ \\
\hline
\end{tabular}

n: number of subjects; IQR: interquartile range 25\%-75\%; MS: multiple sclerosis; EDSS: expanded disability status scale; *Presence of fatigue was identified by means of the NFI-MS/BR cut-off point $(\geq 30)$. 
Table 2. Distribution of scores from instruments in psychometric analysis $(n=210)$.

\begin{tabular}{|c|c|c|}
\hline Instruments & Scale range & Median (IQR) \\
\hline \multicolumn{3}{|l|}{ NFI-MS-BR } \\
\hline Summary & $0-30$ & $19(11.5-23)$ \\
\hline Physical & $0-24$ & $15(9-19)$ \\
\hline Cognitive & $0-12$ & $6(3-9)$ \\
\hline Diurnal Sleep & $0-18$ & $10(7-12)$ \\
\hline Nocturnal Sleep & $0-15$ & $8(5-11)$ \\
\hline Total & $0-69$ & $40(26.5-49)$ \\
\hline FSS & $9-63$ & $41(27-52)$ \\
\hline \multicolumn{3}{|l|}{ MFIS } \\
\hline Physical & $0-36$ & $11(7-17)$ \\
\hline Cognitive & $0-40$ & $7(2-13.5)$ \\
\hline Total & $0-84$ & $22(12-32.5)$ \\
\hline \multicolumn{3}{|l|}{ MSIS-29 } \\
\hline Physical & $0-100$ & $20(9-37)$ \\
\hline Psychological & $0-45$ & $8(4-15)$ \\
\hline Total & $0-145$ & $30(13-51)$ \\
\hline ESS & $0-24$ & $5(2-10)$ \\
\hline PSQUI & $0-21$ & $5(3-9)$ \\
\hline EDSS & $0-10$ & $3(1-4)$ \\
\hline \multicolumn{3}{|c|}{$\begin{array}{l}\text { n: number of subjects; IQR: interquartile range } 25 \%-75 \% \text {; } \\
\text { NFI-MS-BR: Neurological Fatigue Index for Multiple Sclerosis (Brazilian } \\
\text { version); FSS: Fatigue Severity Scale, } \geq 28=\text { presence of MS fatigue symptom } 7 \\
\text { MFIS: Modified Fatigue Impact Scale, } \geq 38 \text { = presence of MS fatigue symptom; } \\
\text { MSIS-29: Multiple Sclerosis Impact Scale; ESS: Epworth Sleepiness } \\
\text { Scale, } \geq 10 \text { points indicates bad sleepiness }{ }^{17} ; \text { PSQUI: Pittsburgh Sleep Quality } \\
\text { Index, } \geq 5=\text { bad quality of sleep }{ }^{17} \text {; EDSS: Expanded Disability Status Scale. }\end{array}$} \\
\hline
\end{tabular}

\section{Psychometric characteristics of the NFI-MS/BR}

The NFI-MS/BR was completed in a median time of 3'56" (3.1-4.3). There were no missing data, ceiling $(4.28 \%$ - first interview, $5.17 \%$ - retest), and nor floor effects ( $4.76 \%$ - first interview, 8.04\% - retest). Good reliability was demonstrated. There was high agreement and small mean intra and interobserver differences (Table 3).

Based on prior hypotheses 41 were tested. All of them were confirmed except 5 out of 10 expected hypotheses about similar subscales (Table 4).

Analysis on ROC curve revealed the NFI-MS/BR $\geq 30$ points as cut-off point to indicate fatigued subjects with value of accuracy of $0.86[0.79 ; 0.92](P<0.001)$ (Figure).

\section{DISCUSSION}

The available existing instruments only provided a limited understanding of the level of fatigue experienced by Brazilians with MS. Thus, gaining the ability to measure this symptom using a cross-culturally adapted instrument with acceptable psychometric properties has important implications for clinical trials and epidemiological studies.

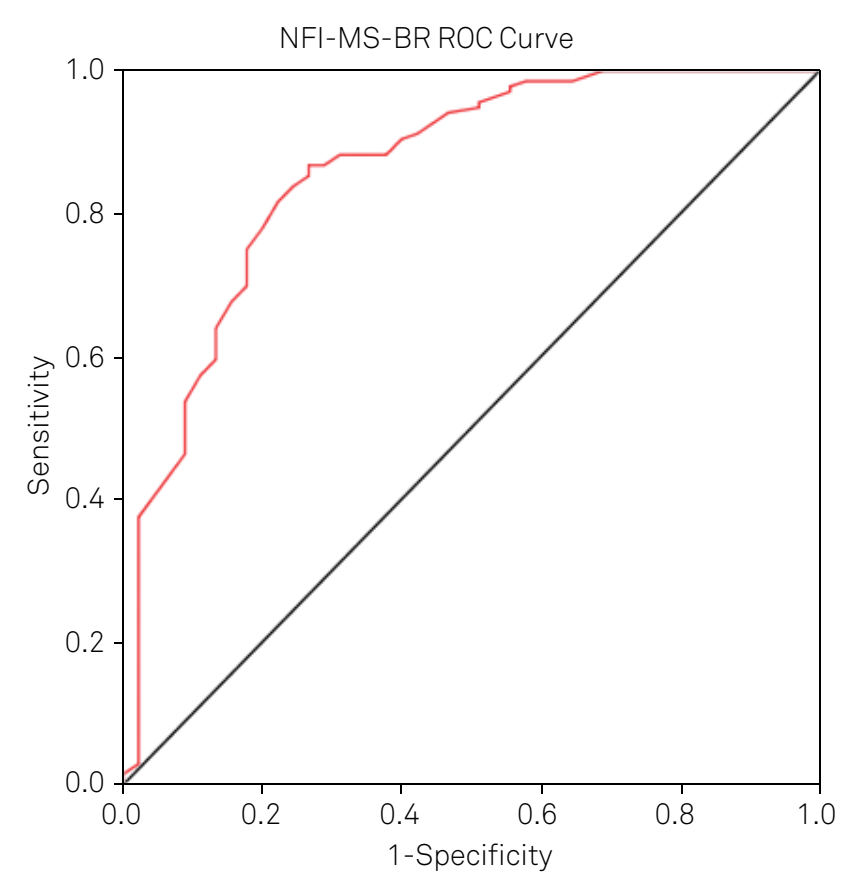

NFI-MS/BR: Neurological Fatigue Index for Multiple Sclerosis; MS: multiple sclerosis.

Figure. Receiver operating characteristic (ROC) curve and the cut-off point for NFI-MS/BR to detect fatigue in MS subjects $(n=210)$. Sensitivity $=86.8 \% ; 1-$ Specificity $=28.9 \%$; Standard erro $r=0.03$; Accuracy $=0.86[0.79-0.92]$.

The demographic and clinical characteristics of the sample were consistent with data in previous studies. The age of onset has unimodal distribution with a peak at between 20 and 30 years of age. The incidence of MS is around two to three times greater among women than men. Correlation studies on racial differences in the MS prevalence rates worldwide have revealed that the Caucasians appears to have a higher risk than other populations ${ }^{22}$. The majority of the subjects in the present study showed the RRMS clinical form as in previous reports, which have shown approximately $80 \%$ of the patients will initially present this form ${ }^{11}$. The sample exhibited low disability. This can be explained due to inclusion criteria, given that all of the MS patients were in clinical remission and most of them presented the RRMS clinical form characterized by lower severity and less disease progression than in other clinical forms.

The frequency of fatigue in this study confirmed the high prevalence demonstrated in various studies, with worldwide rates of up to $90 \%^{1}$ and Brazilian rates of around $67.4 \%$ to $86.7 \%^{23,24}$. This is a subjective finding, and hence there is considerable variability in the description of fatigue. Common definitions include a sense of exhaustion or a subjective lack of physical and/or mental energy that is perceived by the individual or caregiver to interfere with usual or desired activity. However, these terms may be differently interpreted depending on subject's cultural background ${ }^{25}$. 


\begin{tabular}{|c|c|c|c|c|c|c|c|}
\hline \multirow{2}{*}{ NFI-MS/BR (sub)scale } & \multirow{2}{*}{ ICC } & \multirow{2}{*}[95\%\mathrm{Cl}]{} & \multirow{2}{*}{ SEM agreement } & \multicolumn{3}{|c|}{ Bland-Altman } & \multirow{2}{*}{$95 \%$ LC } \\
\hline & & & & $d$ & $95 \% \mathrm{Cl}$ of ${ }^{-1}$ & SD of d & \\
\hline \multicolumn{8}{|l|}{ Summary } \\
\hline Intra-observer & 0.83 & {$[0.74-0.89]$} & 2.2 & -0.81 & $-2.34-0.71$ & 3.24 & $-10.91-7.64$ \\
\hline Interobserver & 0.79 & {$[0.71-0.86]$} & 1.7 & 0.88 & $-2.67-2.82$ & 3.31 & $-8.44-10.67$ \\
\hline \multicolumn{8}{|l|}{ Physical } \\
\hline Intra-observer & 0.86 & {$[0.77-0.93]$} & 1.3 & -0.83 & $-1.37-2.41$ & 4.30 & $-12.03-9.11$ \\
\hline Interobserver & 0.84 & {$[0.74-0.91]$} & 1.4 & 0.87 & $-0.57-2.25$ & 3.80 & $-9.27-11.03$ \\
\hline \multicolumn{8}{|l|}{ Cognitive } \\
\hline Intra-observer & 0.82 & {$[0.73-0.95]$} & 2.5 & -0.80 & $-2.39-0.71$ & 3.47 & $-10.33-7.65$ \\
\hline Interobserver & 0.77 & {$[0.72-0.90]$} & 2.1 & 0.76 & $-0.31-2.27$ & 2.87 & $-8.41-9.73$ \\
\hline \multicolumn{8}{|l|}{ Diurnal sleep and rest } \\
\hline Intra-observer & 0.87 & {$[0.83-0.94]$} & 1.1 & -0.57 & $-2.10-0.63$ & 2.33 & $-11.07-9.32$ \\
\hline Interobserver & 0.85 & {$[0.75-0.92]$} & 1.0 & 0.54 & $-0.30-2.27$ & 3.10 & $-7.43-18.34$ \\
\hline \multicolumn{8}{|c|}{ Nocturnal sleep and sleppiness } \\
\hline Intra-observer & 0.85 & {$[0.81-0.97]$} & 1.8 & -0.62 & $-1.45-2.18$ & 3.32 & $-11.13-9.67$ \\
\hline Interobserver & 0.82 & {$[0.75-0.86]$} & 1.4 & 0.80 & $-0.47-2.15$ & 2.41 & $-9.30-12.12$ \\
\hline
\end{tabular}

NFI-MS/BR: Neurological Fatigue Index for Multiple Sclerosis (Brazilian version); ICC: Intraclass correlation coefficient; Cl: confidence interval; $d$ : mean difference; SD: standard deviation; LC: limits of agreement; SEM: standard error of measurement.

Table 4. Spearman's correlation coefficients (rho) between individual subscales of the NFI-MS/BR and other instruments $(\mathrm{n}=180$ ).

\begin{tabular}{|c|c|c|c|c|c|c|}
\hline \multirow[b]{2}{*}{$\begin{array}{l}\text { INSTRUMENTS } \\
\text { Subscales }\end{array}$} & \multirow[b]{2}{*}{ Total } & \multicolumn{5}{|c|}{ NFI-MS/BR (rho) } \\
\hline & & Summary & Physical & Cognitive & Diurnal Sleep & $\begin{array}{l}\text { Nocturnal } \\
\text { Sleep }\end{array}$ \\
\hline Summary & 0.92 & - & - & - & - & - \\
\hline NFI-MS Physical & 0.90 & 0.96 & - & - & - & - \\
\hline NFI-MS Cognitive & 0.82 & 0.86 & 0.72 & - & - & - \\
\hline NFI-MS Diurnal Sleep & 0.65 & 0.46 & 0.45 & 0.38 & - & - \\
\hline NFI-MS Nocturnal Sleep & 0.79 & 0.60 & 0.58 & 0.56 & 0.45 & - \\
\hline MFIS Physical & 0.73 & 0.74 & 0.78 & 0.55 & 0.41 & 0.52 \\
\hline MFIS Cognitive & 0.59 & 0.59 & 0.50 & 0.76 & 0.29 & 0.43 \\
\hline MFIS Psychosocial & 0.64 & 0.65 & 0.67 & 0.58 & 0.34 & 0.45 \\
\hline FSS & 0.69 & 0.71 & 0.76 & 0.59 & 0.43 & 0.45 \\
\hline MSIS-29 Physical & 0.73 & 0.75 & 0.76 & 0.59 & 0.38 & 0.53 \\
\hline MSIS-29 Psychological & 0.59 & 0.53 & 0.50 & 0.78 & 0.27 & 0.51 \\
\hline ESS & 0.33 & 0.21 & 0.26 & 0.25 & $0.35^{\star}$ & 0.36 * \\
\hline PSQUI & 0.58 & 0.52 & 0.53 & 0.42 & $0.35^{\star}$ & $0.56^{*}$ \\
\hline EDSS & 0.48 & 0.53 & 0.56 & 0.35 & 0.28 & 0.25 \\
\hline
\end{tabular}

NFI-MS/BR: Neurological Fatigue Index for Multiple Sclerosis (Brazilian version); MFIS: Modified Fatigue Impact Scale; FSS: Fatigue Severity Scale; MSIS-29: Multiple Sclerosis Impact Scale; ESS: Epworth Sleepiness Scale; PSQUI: Pittsburgh Sleep Quality Index; EDSS: Expanded Disability Status Scale; *Correlation did not fulfill a priori expectations.

Each society has its own beliefs, attitudes, customs and behavior and, in the cross-cultural adaptation process, the particularities of each country need to be taken into consideration ${ }^{25}$. The steps for the cross-cultural adaptation process proposed ${ }^{16}$ were followed: all the equivalences between the NFI-MS and NFI-MS/BR were investigated within the context of Brazilian culture, and content and face validity were achieved. The meticulous process used in this study was important for identifying potential problems with the instrument content. Through assuring these equivalences, it was expected to maintain the psychometric properties of the NFI-MS/BR as properly documented in prior studies ${ }^{5,11,12,13}$. 
It has been recognized that for such an instrument to be clinically useful, it needs to be validated, appropriate for the disease in question, reliable and easy to interpret and filled out ${ }^{25}$. The NFI-MS/BR showed a good level of patient acceptability and required only a few minutes to complete, as seen in previous studies ${ }^{5,13}$. Acceptability is supported when the scores observed are also well distributed ${ }^{20}$.

Measurements of reproducibility are indicators of good reliability. The reproducibility of the NFI-MS/BR was as good as the original version ${ }^{5}$ (ICC $=0.79$ to 0.86 ) and the Dutch version (ICC $=0.75$ to 0.83 ) and showed small SEM on all (sub) scales as the Dutch version ${ }^{13}$. The SEM allows one to make statements about the precision of test scores of individual examinees and to interpret score differences on instruments. The lower difference, the better is an instrument to obtain more realistic scores ${ }^{21}$.

The Bland-Altman analysis demonstrated that there was low individual variability with satisfactory limits of agreement, such that the subjects answered the items similarly seven days later. These results suggest that the NFI-MS/BR is a stable instrument, similar to its Dutch version ${ }^{13}$, which demonstrated low systematic difference $(d=-0.07)$.

Investigating the validity of MS fatigue instruments is not a simple task because of the unclear definition, complexity and multidimensional factors of fatigue, with many possibilities of expected associations. When an instrument is valid, it truly reflects the concept that it should measure ${ }^{17}$. There are three main different aspects of validity: content validity, criterion validity and construct validity ${ }^{10}$. Content validity has already been commented on, in describing the stage of cross-cultural adaptation. Since no gold standard exists for fatigue instruments, criterion validity was not evaluated.

Construct validity was defined as the degree to which scores of a questionnaire are consistent with the hypothesis $^{17}$. Considering limitations relating to the most widely used instruments for assessing MS fatigue (FSS and MFIS) ${ }^{4,6,12}$, hypotheses were made to include other instruments, so as to attribute more evidence for checking the construct validity of the NFI-MS/BR. Even though the correlation scores turned out to be very low between the nonsimilar subscales of the instruments that measure the same construct all the hypotheses were confirmed. However between the similar subscales the correlations of NFI-MS physical and EDSS and NFI-MS subscales related to sleep conditions and ESS and PSQUI were not confirmed. These results are consistent with the majority of similar correlations in previous studies on NFI-MS validation ${ }^{5,13}$.

The physical subscales of the NFI-MS/BR, MFIS and FSS demonstrated the highest values. This finding is supported by evidence that relates fatigue as a primarily physical symptom $^{2,12}$. The physical component of fatigue has been shown in many studies as a factor that interferes with activities of daily living and has an impact on quality of life $\mathrm{e}^{5,11}$.
Studies on the NFI-MS ${ }^{5,11,12}$ have required comparisons between the NFI-MS and sleep scales, thus suggesting that MS fatigue is probably associated with low sleep quality during the night and sleepiness during the day. These associations were not confirmed in this study. As an unexpected result, there were low or moderate correlations between the NFI-MS/BR subscales relating to sleep and specific instruments that measure sleep, although there is no other evidence to compare with this data. One possible explanation might be that the NFI-MS/BR is a specific instrument for measuring MS fatigue, while ESS and PSQUI are generic for MS subjects. On the other hand, there is agreement that fatigue and sleepiness, which are both subjective phenomena, should be measured as two independent constructs, in order to avoid confusion ${ }^{26}$. The correlations that were found provided convincing evidence that supported the construct validity of the NFI-MS/BR, as also seen with the original NFI-MS ${ }^{5}$ and its Dutch version ${ }^{13}$.

Before the present study, no cut-off point for the NFI-MS had been reported. Sensitivity is an important psychometric property that helps to enable interpretation of clinical implications because it allows questionnaires to be used as diagnostic or predictive instruments ${ }^{20}$.

The limitations for the results need to be considered. With regard to the assessment of reliability, and the difference from the original ${ }^{5}$ and the Dutch version of NFI-MS ${ }^{13}$, the mode of administration (mailed questionnaires) may have influenced, whereas the current study was administered by interviewers. This could be an explanation why the ICCs found in this study were higher than in the other studies. Another limitation is that FSS and MFIS were used as comparator instruments despite their problems regarding reliability and validity ${ }^{4,6}$. These were administered in the present study because there were no other Brazilian specific instrument for assessing MS fatigue. With regard to use of the sleep instruments, it is important to emphasize that these are generic measurements, and may fail to address important areas of impact that are disease-specific.

Further research is required in order to be able to administer the NFI-MS/BR. Future studies could correlated it with imaging examinations and with other samples such as patients in hospital, with the progressive clinical form, with higher EDSS, or during MS relapses. A longitudinal study with a greater length of follow-up among those expected to change could determine the responsiveness of the NFI-MS/BR.

In conclusion the NFI-MS/BR is the first specific questionnaire available in Brazil that satisfies the modern standards for outcome measurements relating to the symptom of fatigue in MS. It is a valid and reliable instrument that can be administered rapidly and is easily comprehended. It can be used in clinical settings as well as in any design of research study. 
1. Induruwa I, Constantinescu CS, Gran B. Fatigue in multiple sclerosis: a brief review. J Neurol Sci. 2012;323(1-2):9-15. doi:10.1016/j.jns.2012.08.007

2. Krupp LB, LaRocca NG, Muir-Nash J, Steinberg AD. The fatigue severity scale. Application to patients with multiple sclerosis and systemic lupus erythematosus. Arch Neurol. 1989; 46(10):1121-3. doi:10.1001/archneur.1989.00520460115022

3. Fischer JS, LaRocca NG, Miller DM, Ritvo P.G, Andrews H, Paty D. Recent developments in the assessment of quality of life in multiple sclerosis (MS). Mult Scler. 1999;5(4):251-9. doi:10.1177/135245859900500410

4. Mills R, Young C, Nicholas R, Pallant J, Tennant A. Rasch analysis of the Fatigue Severity Scale in multiple sclerosis. Mult Scler. 2009;15(1):81-7. doi:10.1177/1352458508096215

5. Mills RJ, Young CA, Pallant J.F, Tennant A. Development of a patient reported outcome scale for fatigue in multiple sclerosis: The Neurological Fatigue Index (NFI-MS). Health Qual Life Outcomes. 2010;8:22. doi:10.1186/1477-7525-8-22

6. Mills RJ, Young CA, Pallant J, Tennant A. Rasch analysis of the Modified Fatigue Impact Scale (MFIS) in multiple sclerosis. J Neurol Neurosurg Psychiatry. 2010;81(9):1049-51. doi:10.1136/jnnp.2008.151340

7. Mendes MF, Tilbery CP, Felipe E. [Fatigue and multiple sclerosis: preliminary study of 15 patients with self-reported scales]. Arq Neuropsiquiatr. 2000;58(2B):467-70. Portuguese. doi:10.1590/S0004-282X2000000300011

8. Pavan K, Schmidt K, Marangoni B, Mendes MF, Tilbery CP, Lianza S. [Multiple sclerosis: cross-cultural adaptation and validation of the modified fatigue impact scale]. Arq Neuropsiquiatr. 2007;65(3A):669-73. Portuguese. doi:10.1590/S0004-282X2007000400024

9. Cook KF, Bamer AM, Roddey TS, Kraft GH, Kim J, Amtmann D. A PROMIS fatigue short form for use by individuals who have multiple sclerosis. Qual Life Res. 2012;21(6):1021-30. doi:10.1007/s11136-011-0011-8

10. Elbers RY, Rietberg MB, van Wegen EE, Verhoef J, Kramer SF, Terwee CB et al. Self-report fatigue questionnaires in multiple sclerosis, Parkinson's disease and stroke: a systematic review of measurement properties. Qual Life Res. 2012;21(6):925-44. doi:10.1007/s11136-011-0009-2

11. Mills RJ, Young CA. The relationship between fatigue and other clinical features of multiple sclerosis. Mult Scler. 2011;17(5):604-12. doi:10.1177/1352458510392262

12. Mills RJ, Calabresi M, Tennant A, Young CA. Perceived changes and minimum clinically important difference of the Neurological Fatigue Index for multiple sclerosis (NFI-MS). Mult Scler.; 2013;19(4):502-5. doi:10.1177/1352458512457840

13. Derksen A, Mokkink LB, Rietberg MB, Knol DL, Ostelo RWJG, Uitdehaag BMJ.Validation of a Dutch version of the Neurological
Fatigue Index (NFI-MS) for patients with multiple sclerosis in the Netherlands. Qual Life Res. 2013;22(9):2435-41. doi:10.1007/s11136-013-0375-z

14. Polman $\mathrm{CH}$, Reingold SC, Banwell B, Clanet M, Cohen JA, Filippi $M$ et al. Diagnostic criteria for multiple sclerosis: 2010 revisions to the McDonald criteria. Ann Neurol. 2011;69(2):292-302. doi:10.1002/ana.2236

15. Kurtzke JF. Rating neurologic impairment in multiple sclerosis: an expanded disability status scale (EDSS). Neurology. 1983;33(11):1444-52. doi:10.1212/WNL.33.11.1444

16. Beaton DE, Bombardier C, Guillemin F, Ferraz MB. Guidelines for the process of cross-cultural adaptation of self-report measures. Spine. 2000;25(24):3186-91. doi:10.1097/00007632-200012150-00014

17. Mokkink LB, Terwee CB, Patrick DL, Alonso J, Stratford PW, Knol $\mathrm{DL}$ et al. The COSMIN study reached international consensus on taxonomy, terminology, and definitions of measurement properties for health-related patient-reported outcomes. J Clin Epidemiol. 2010;63(7):737-45. doi:10.1016/j.jclinepi.2010.02.006

18. Lopes J, Kaimen-Maciel DR, Matsuo T. [Cross-cultural adaptation and validation of multiple sclerosis impact scale]. Rev Neurocien. 2011;19(3):433-40.

19. Bertolazi NA. Tradução, adaptação cultural e validação de dois instrumentos de avaliação do sono: Escala de sonolência de Epworth e Índice de qualidade de sono de Pittsburgh [thesis]. Porto Alegre: Universidade Federal do Rio Grande do Sul; 2008.

20. Scientific Advisory Committee of the Medical Outcomes Trust. Instrument review criteria. Washington, DC: Scientific Advisory Committee; 1995.

21. Terwee CB, Bot SD, De Boer MR, van der Windt DA, Knol DL, Dekker $J$ et al. Quality criteria were proposed for measurement properties of health status questionnaires. J Clin Epidemiol. 2007;60(1):34-42. doi:10.1016/j.jclinepi.2006.03.012

22. Sospedra M, Martin R: Immunology of multiple sclerosis. Annu Rev Immunol. 2005;23(1):683-747. doi:10.1146/annurev.immunol.23.021704.11570

23. Mendes MF, Tilbery HP, Balsimell S, Felipe E, Moreira MA, BarãoCruz AM. [Fatigue in multiple sclerosis relapsing-remitting form]. Arq Neuropsiquiatr. 2000;58(2B):471-5. Portuguese. doi:10.1590/S0004-282X2000000300012

24. Lopes KN, Nogueira LAC, Nóbrega FR, Alvarenga-Filho H, Alvarenga RMP. [Impairment, fatigue, and quality of life in progressive primary form of Multiple Sclerosis]. Rev Neurocien. 2010;18(1):13-7. Portuguese.

25. Weeks A, Swerissen H, Belfrage J: Issues, challenges, and solutions in translating study instruments. Eval Rev. 2007;31(2):153-65. doi:10.1177/0193841X06294184

26. Veauthier C, Blau A, Paul F. "Obstructive sleep apnea is associated with fatigue in multiple sclerosis" by Kaminska et al. Mult Scler. 2013;19(3):372-3. doi:10.1177/1352458512446037 
NFI-MS/BR

ÍNDICE NEUROLÓGICO DE FADIGA PARA ESCLEROSE MÚLTIPLA (NFI-MS/BR)

Instruções: Para cada afirmação, responda como você tem se sentido no último mês.

1. Eu fico cansado facilmente.

$\square$ Discordo totalmente

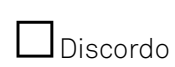

Concordo

Concordo totalmente

2. Às vezes sinto meu corpo fraco.

$\square$ Discordo totalmente

$\square$ Discordo

Concordo

Concordo totalmente

3. Meus braços e/ou pernas podem se tornar muito pesados.

$\square$ Discordo totalmente $\quad \square$ Discordo

$\square$ Concordo

Concordo totalmente

4. Meu corpo não consegue acompanhar o que eu tenho vontade de fazer.

$\square$ Discordo totalmente

$\square$ Discordo

Concordo

$\square$ Concordo totalmente

5. Quanto mais tempo eu levo fazendo alguma coisa, mais difícil ela fica.

$\square$ Discordo totalmente

$\square$ Discordo

Concordo

Concordo totalmente

6.Às vezes eu não tenho escolha a não ser parar o que estou fazendo.

Discordo totalmente

Discordo

Concordo

Concordo totalmente

7. Eu fico cansado quase todos os dias.

$\square$ Discordo totalmente

$\square$ Discordo

$\square$ Concordo

$\square$ Concordo totalmente

8. Eu me sinto fraco mesmo sem ter feito nada.

Discordo totalmente $\square$ Discordo

Concordo

Concordo totalmente

9. Às vezes eu tenho que me concentrar muito para fazer coisas simples.

$\square$ Discordo totalmente

$\square$ Discordo

Concordo

Concordo totalmente

10. É mais difícil falar quando estou cansado.

$\square$ Discordo totalmente

$\square$ Discordo

Concordo

Concordo totalmente

11. Conforme o dia passa, fica mais difícil organizar e realizar minhas atividades.
$\square$ Discordo totalmente
$\square$ Discordo
$\square$ Concordo

$\square$ Concordo totalmente

12. Esforço mental realmente exige muito de mim.

$\square$ Discordo totalmente $\square$ Discordo

Concordo

Concordo totalmente

13. Eu necessito descansar durante o dia.

Discordo totalmente

$\square$ Discordo

Concordo

Concordo totalmente

14. Eu necessito dormir durante o dia.

$\square$ Discordo totalmente

$\square$ Discordo

Concordo

Concordo totalmente

15. Dormir durante o dia realmente me ajuda.

Discordo totalmente

$\square$ Discordo

Concordo

Concordo totalmente 
16. Eu necessito descansar para continuar minhas atividades.

$\square$ Discordo totalmente $\square$ Discordo $\quad \square$ Concordo $\quad \square$ Concordo totalmente

17. Eu tento fazer todas as minhas atividades durante a manhã.

Discordo totalmente

Discordo

Concordo

Concordo totalmente

18. Quando vou fazer alguma atividade que exija muito esforço, eu tento descansar ou dormir antes.

$\square$ Discordo totalmente

Discordo

$\square$ Concordo

Concordo totalmente

19. Eu sinto como se estivesse há algumas noites sem dormir.

$\square$ Discordo totalmente

$\square$ Discordo

$\square$ Concordo

$\square$ Concordo totalmente

20. Eu bocejo muito (abro muito a boca quando estou com sono ou cansado).

$\square$ Discordo totalmente

Discordo

$\square$ Concordo

Concordo totalmente

21. Às vezes eu acordo durante à noite sem nenhum motivo.

$\square$ Discordo totalmente $\square$ Discordo

22. Quando eu acordo de manhã, sinto que não descansei.
$\square$ Discordo totalmente
$\square$ Discordo
$\square$ Concordo
Concordo totalmente

23. Frequentemente de manhã, eu não sinto vontade de levantar da cama porque estou com muito sono ou cansaço.
$\square$ Discordo totalmente
Discordo
Concordo
Concordo totalmente

Índice Neurológico de Fadiga, ( 2013

Todos os direitos reservados à Universidade de Leeds 